1992

INDEX

Articles

by Author
Adams, Frederick, and Alfred R. Mele,

The Intention/Volition Debate . . . . . . . . . . 323

Bahlul, Raja, Identity and Necessary Similarity . . . . . 531

Bar-On, Dorit, and Mark Risjord,

Is There Such A Thing As A Language? . . . . . . . 163

Brown, Bryson, Defending Backwards Causation . . . . . 429

Chazan, Pauline, Pride, Virtue, and Self-Hood:

A Reconstruction of Hume . . . . . . . . . . . . 45

Cohen, Joshua, Okin on Justice, Gender, and Family . . . 263

Collier, John D., Critical Notice of Paul Thompson,

The Structure of Biological Theories . . . . . 287

Dillon, Robin S., Respect and Care:

Toward Moral Integration . . . . . . . . . . . . . . 105

Double, Richard, Two Types of Autonomy Accounts . . . 65

Dretske, Fred, The Metaphysics of Freedom . . . . . . . 1

Ellis, Brian, Critical Notice of Cheryl Misak,

Truth And The End Of Inquiry:

A Peircean Account of Truth

Fine, Gail, Critical Notice of R.M. Dancy,

Two Studies in the Early Academy . . . . . . . 393

Fisk, Milton, Justifying Democracy . . . . . . . . . . 463

Haji, Ishtiyaque, A Riddle Regarding Omissions . . . . 485

Hardin, Russell, Efficiency Vs. Equality and

the Demise of Socialism . . . . . . . . . . . . . . 149

Hausman, Alan, and David Hausman,

Descartes's Secular Semantics . . . . . . . . . . . . 81

Jacobson, Stephen, Alston on Iterative

Foundationalism and Cartesian Epistemology . . . . . 133

Lammenranta, Markus, Goodman's Semiotic

Theory of Art . . . . . . . . . . . . . . . . . 339

MacIntosh, Duncan, Preference-Revision and

the Paradoxes of Instrumental Rationality . . . . . . . 503

MacIntosh, J.J., Adverbs, Identity, and

Multiple Personalities . . . . . . . . . . . . . . . 301

Misak, Cheryl, Critical Notice of Brian Ellis,

Truth and Objectivity . . . . . . . . . . . . 365

Neumann, Michael, Needs Not Rights . . . . . . . . 353

Sorensen, Roy A., Thought Experiments and the Epistemology of Laws . . . . . . . . . . . . . . 15

Sparshott, Francis, Critical Notice of

Thomas C. Brickhouse and Nicholas D. Smith,

Socrates on Trial and Critical Notice of

Gregory Vlastos, Socrates, Ironist and

Moral Philosopher: The Townsend Lectures . . . 411 
Stewart, Robert M., Butler's Argument

Against Psychological Hedonism . . . . . . . . . . . 211

Stroll, Avrum, Reflections on Surfaces . . . . . . . 191

Stone, Mark A., Realism and the Principle of

the Common Cause . . . . . . . . . . . . . . . 445

Thom, Paul, Critical Notice of F.J. Pelletier,

Parmenides, Plato, and the Problem

of Non-Being . . . . . . . . . . . . . . 573

Timmons, Mark, Necessitation and

Justification in Kant's Ethics . . . . . . . . . . 223

Woods, John, Critical Notice of W.V. Quine,

Pursuit of Truth . . . . . . . . . . . . . . . 547 
1992

INDEX

Articles

by Title

Adverbs, Identity, and Multiple Personalities,

J.J. MacIntosh . . . . . . . . . . . . . . . 301

Alston on Iterative Foundationalism and

Cartesian Epistemology, Stephen Jacobson . . . . . . 133

Butler's Argument Against Psychological

Hedonism, Robert M. Stewart . . . . . . . . . . . 211

Critical Notice of Thomas C. Brickhouse and

Nicholas D. Smith, Socrates on Trial, and

Critical Notice of Gregory Vlastos, Socrates,

Ironist and Moral Philosopher:

The Townsend Lectures, Francis Sparshott . . . . . 411

Critical Notice of R.M. Dancy, Two Studies

in the Early Academy, Gail Fine . . . . . . . . . . 393

Critical Notice of Brian Ellis, Truth and

Objectivity, Cheryl Misak . . . . . . . . . . . . . 365

Critical Notice of Cheryl Misak, Truth and

The End of Inquiry: A Peircean Account

of Truth, Brian Ellis . . . . . . . . . . . . . . . 381

Critical Notice of F.J. Pelletier, Parmenides, Plato, and the Problem of Non-Being, Paul Thom . . . . . 573

Critical Notice of W.V. Quine, Pursuit of

Truth, John Woods . . . . . . . . . . . . . . 547

Critical Notice of Paul Thompson, The Structure

of Biological Theories, John D. Collier . . . . . . 287

Defending Backwards Causation, Bryson Brown . . . 429

Descartes's Secular Semantics, Alan Hausman

and David Hausman . . . . . . . . . . . . . . . 81

Efficiency Vs. Equality and the Demise of

Socialism, Russell Hardin . . . . . . . . . . . . . 149

Goodman's Semiotic Theory of Art,

Markus Lammenranta . . . . . . . . . . . . . . 339

Identity and Necessary Similarity, Raja Bahlul . . . . 531

The Intention/Volition Debate,

Frederick Adams and Alfred R. Mele . . . . . . . . 323

Is There Such A Thing As A Language?

Dorit Bar-On and Mark Risjord . . . . . . . . . . . 163

Justifying Democracy, Milton Fisk . . . . . . . . . 463

The Metaphysics of Freedom, Fred Dretske . . . . . . 1

Necessitation and Justification in Kant's Ethics,

Mark Timmons . . . . . . . . . . . . . . . 223

Needs Not Rights, Michael Neumann . . . . . . . . 353

Okin on Justice, Gender, and Family, Joshua Cohen . 263

Preference-Revision and the Paradoxes of

Instrumental Rationality, Duncan MacIntosh . . . . 503 
Pride, Virtue, and Self-Hood:

A Reconstruction of Hume, Pauline Chazan . . . . 45

Realism and the Principle of the Common

Cause, Mark A. Stone . . . . . . . . . . . . . . 445

A Riddle Regarding Omissions, Ishtiyaque Haji $\ldots 485$

Reflections on Surfaces, Avrum Stroll . . . . . . . . 191

Respect and Care: Toward Moral Integration,

Robin S. Dillon . . . . . . . . . . . . . . . 105

Thought Experiments And The Epistemology

of Laws, Roy A. Sorensen . . . . . . . . . . . . 15

Two Types of Automony Accounts, Richard Double . . 65 
Information for Authors
The purpose of the Canadian Journal of Philosophy is the publication in Canada of philosophical work of high quality, in English or French, and in any field of philosophy. All submissions are given blind editorial review; those of departmental colleagues are externally refereed.

Manuscripts should be sent in triplicate to: Executive Secretary, Canadian Journal of Philosophy, Department of Philosophy, University of Lethbridge, Lethbridge, Alberta, Canada T1K 3M4. It is preferred that manuscripts be typed double-spaced, including quotes and footnotes. In general, the Canadian Journal of Philosophy follows The University of Chicago Manual of Style. Footnotes should be numbered consecutively and assembled on separate pages at the end of the manuscript. Manuscripts will not be returned unless return postage is prepaid by cheque, money-order, reply coupons, or Canadian stamps.

Authors will receive, without charge, 25 copies of their articles. Additional offprints may be ordered when the proofs are returned to the publisher.

The articles in C.J.P. are indexed in The Philosophers' Index, Bowling Green, Ohio, U.S.A., in the Reportoire bibliographique de la philosophie, Louvain, Belgium, and in the Canadian Periodical Index.

All enquiries of an editorial nature should be directed to the Executive Secretary at the above address.

\section{Avis aux auteurs}

The Canadian Journal of Philosophy a pour objet la publication canadienne, en langues anglaise ou française, d'études philosophiques de haut niveau, quel que soit le domaine philosophique auxquelles elles appartiennent. Les communications sont évaluées dans l'anonymat de leurs auteurs; celles que soumettent les collègues départementaux sont référées à un comité de lecture extérieur.

Les manuscrits, en triple exemplaire, doivent être adressés à La Secrétaire de Rédaction. Canadian Journal of Philosophy, University of Lethbridge, Lethbridge, Alberta, Canada T1K 3M4. Soumettre de préférence des manuscrits (citations et notes comprises) dactylographiés à double interligne, en prenant pour guide, dans la mesure du possible, The University of Chicago Manual of Style. Les notes doivent suivre la numérotation continue et figurer sur des feuilles indépendantes en annexe au manuscrit. Les textes non insérés ne sont rendus qu'en cas de prépaiement des frais de poste par chèque, mandat, coupons-réponse ou timbres canadiens.

Les auteurs recoivent gratuitement 25 tirés-à part de leur article. Ils sont priés, s'ils désirent en obtenir un plus grand nombre à titre onéreux, en informer l'imprimeur lors du renvoi des épreuves.

Les articles $\mathrm{du}$ C.J.P. sont catalogués dans The Philosopher's Index, Bowling Green, Ohio, E.-U., dans le Répertoire bibliographique de la philosophie, Louvain, Belgique, et dans l'Index de Périodiques Canadiens. 
Subscription Information
The Canadian Journal of Philosophy is published by the University of Calgary Press.

The Canadian Journal of Philosophy is published quarterly, in March, June, September and December. In addition to these regular issues, the C.J.P. publishes annually a supplementary volume of original papers on a selected theme of contemporary philosophical interest. This supplementary volume is free to individual and student subscribers to the journal in that year. Supplementary volumes may also be purchased separately.

Correspondence regarding subscriptions, renewals, single issues and supplementary volume orders should be addressed to Canadian Journal of Philosophy c/o The University of Calgary Press, University of Calgary, Calgary, Alberta, Canada T2N 1 N4.

A subscription for the 1993 volume of four issues is:

$\begin{array}{lrr} & \text { Canada } & \text { Outside Canada } \\ \text { Institutions } & \text { Cdn. } \$ 40.00 & \text { US } \$ 40.00 \\ \text { Individuals } & 25.00 & 25.00 \\ \text { Students } & 15.00 & 15.00 \\ \text { Single issues } & 9.00 & 9.00\end{array}$

A joint subscription to Canadian Journal of Philosophy and the Australasian Journal of Philosophy is available to individuals at $\$ 40$ and to students at $\$ 25$. Outside Canada price is in US dollars. Canadian residents please add 7\% GST.
The University of Calgary Press, The University of Calgary, CALGARY, Alberta, Canada T2N $1 \mathrm{~N} 4$
1993 Subscription $\square$ 1993 Joint Subscription $\square$

Back Issue $\square$ No.
Individual $\square$ Student $\square$

Please send me information on C.J.P. Supplementary Volumes $\square$

Name

Address

City

Country Postal Code

Visa $\square \quad$ Mastercard $\square \quad$ No.

Expiry Date Signature

Cheques should be made payable to The University of Calgary Press. 


\section{Abonnements}

The Canadian Journal of Philosophy est publié par The University of Calgary Press.

The Canadian Journal of Philosophy est une publication trimestrielle paraissant en mars, juin, septembre et octobre. Outre ses quatre fascicules réguliers, il publie, annuellement, un supplément thématique d'articles inédits consacrés à des sujets d'actualité philosophique. Le supplément est offert gratuitement à tout abonné - particulier ou étudiant - de l'année courante. Les suppléments sont également disponibles à titre onéreux.

Toute correspondance concernant l'administration (abonnements, renouvellements, commandes de numéros et de suppléments) doit être adressée à The Canadian Journal of Philosophy, c/o The University of Calgary Press, The University of Calgary, Calgary, Alberta, Canada T2N 1N4.

Tarifs d'abonnement au volume 1993 (4 fascicules):

$\begin{array}{lrr} & \text { Canada } & \text { Hors-Canada } \\ \text { Institutions } & \text { Cdn. } \$ 40.00 & \text { US } \$ 40.00 \\ \text { Individus } & 25.00 & 25.00 \\ \text { Etudiants } & 15.00 & 15.00 \\ \text { Numéro simple } & 9.00 & 9.00\end{array}$

Tout individu ou étudiant peut souscrire, à raison de $\$ 40$ et $\$ 25$ respectivement, un double abonnement au Canadian Journal of Philosophy et à l'Australasian Journal of Philosophy. Règlement en dollars US pour tous ceux qui résident en dehors du Canada. Les résidents du Canada doivent payé la TPS.

\section{OCanadian

The University of Calgary Press, The University of Calgary, CALGARY, Alberta, Canada T2N 1N4

\begin{tabular}{rr} 
Abonnement $1993 \square$ & Individu $\square$ \\
Double Abonnement 1993 $\square$ & Etudiant $\square$ \\
Numéros disponsibles $\square$ No. & \\
\hline
\end{tabular}

Abonnement $1993 \square \quad$ Individu $\square$ Numéros disponsibles $\square$ No.

Veuillez me faire parvenir tous les renseignements concernant les suppléments du C.J.P.

Nom

Adresse

Ville

Pays Code Postal

Visa $\square \quad$ Mastercard $\square \quad$ No.

Date d'expiration Signature

Libeller tout chèque à l'ordre de The University of Calgary Press. 
Other
Business
Information

Automatic

Permission

to Reproduce

\section{Back Issues}

\section{Services administratifs - détails supplémen- taires}

\section{Reproduction affranchie d'agrément préalable}

\section{Volumes antérieurs}

All business correspondence, should be addressed to Canadian Journal of Philosophy, University of Calgary Press, Calgary, Alberta T2N 1N4. This includes enquiries concerning advertising and promotion, exchanges, and reprinting. The copyright for all materials appearing in the regular issues and in the supplements of this journal is held by the Canadian Journal of Philosophy, and consent for any reproduction or reprinting must be obtained with the following exception.

Permission to reproduce parts of individual numbers of Canadian Journal of Philosophy by photocopy, xerox, offset, etc., for scholarly purposes (but not for republishing by printing nor for sale to the public) is automatically granted without prior permission being secured at the following rates: first 5 copies, no charge; 4 cents for each copy in excess of five of each page of C.J.P.

Remuneration is to be paid to the Canadian Journal of Philosophy, stating title and author of the article and number of copies. Proceeds above $\$ 10.00$ from any one article will be shared with the author. This announcement applies retroactively to volume I, number 1 .

Canadian Journal of Philosophy is indexed in Canadian Magazine Index by Micromedia Limited. Back volumes are available in microform from Micromedia Limited, 158 Pearl St., Toronto M5H 1 L3. 416-593-5211.

Toute correspondance administrative, à l'exception de celle qui concerne les abonnements, renouvellements et commandes de numéros et de suppléments, doit être adressée aux Canadian Journal of Philosophy, University of Calgary Press, Calgary, Alberta T2N 1N4. Ecrire à l'adresse ci-dessus pour tous renseignements relatifs à la publicité et à la promotion, ainsi qu'aux échanges et aux réimpressions. Le copyright des articles afférents aux fascicules et suppléments est propriété du Canadian Journal of Philosophy. Leur reproduction ou réimpression en tout ou partie ne peut être faite sans l'agrément préalable de le Directeur de la Publication, sauf dans le cas suivant.

Est affranchie d'agrément préalable la reproduction partielle des numéros du Canadian Journal of Philosophy par procédé technique de photocopie, xerox, offset, etc., lorsqu'elle vise exclusivement à des fins ou à des recherches académiques. Est interdite toute réimpression ayant pour objet la vente au public. Conditions tarifaires de reproduction: 0-5 copies, accordé à titre gracieux; 6 copies ou en plus, 4 cents pour chaque copie de chaque page du C.J.P.

Effectuer tout règlement à l'ordre du Canadian Journal of Philosophy. Avoir soin d'indiquer le nom de l'auteur et le titre de l'article à reproduire d'une part, et le nombre de copies requises, de l'autre. Les apports provenant $\mathrm{d}^{\prime} \mathrm{un}$ article sont partagés à égalité avec son auteur pour la part numéraire dépassant $\$ 10.00$ (règlement rétroactif au volume I, No. 1).

Canadian Journal of Philosophy est répertoirié par Micromedia ltée dans le Canadian Magazine Index et les volumes antérieurs sont disponibles en microforme chez Micromedia ltée, 158 Pearl St., Toronto M5H 1L3. 416-593-5211. 


\section{Ð 9 CANADIAN JOURNAL OF PHILOSOPHY SUPPLEMENTARY VOLUME 13, 1987 \\ SCIENCE, MORALITY AND FEMINIST THEORY EDITORS: \\ Marsha Hanen and Kai Nielsen \\ Marsha Hanen \\ Alison M. Jaggar \\ Annette C. Baier \\ Alison Wylie \\ Sandra Harding \\ Marilyn Friedman \\ Sex Inequality and Bias in Sex Differences Research \\ The Need for More Than Justice \\ The Philosophy of Ambivalence: Sandra Harding on The Science Question in Feminism \\ Virginia Held \\ Sibyl Schwarzenbach \\ John Exdell \\ Kathryn Morgan \\ Steven Burns \\ Barbara Houston \\ Susan Sherwin \\ Christine Overall \\ Sheila Mullett \\ Ann Ferguson \\ Lorraine Code \\ Kai Nielsen \\ Ascetic Intellectual Opportunities: Reply to Alison Wylie \\ Beyond Caring: The De-Moralization of Gender \\ Non-Contractual Society \\ Rawls and Ownership: The Forgotten Category of Reproductive Labour \\ Ethics, Ideology, and Feminine Virtue \\ Women and Moral Madness \\ Moral Sanity or Who Killed Boy Staunton \\ Rescuing Womanly Virtues: Some Dangers of Moral Reclamation \\ Feminist Ethics and In Vitro Fertilization \\ Surrogate Motherhood \\ Only Connect: The Place of Self-Knowledge in Ethics \\ A Feminist Aspect Therapy of the Self Second Persons \\ Afterword: Feminist Theory - Some Twistings and Turnings}

PRICE: CDN $\$ 14.00$ (in Canada) US $\$ 12.00$ (outside Canada)

Postage: Canada/US: $\$ 2.50$ first book, $\$ 1.00$ each addl. book. Outside North America: $\$ 4.00$ first book, $\$ 2.00$ each addl. book.

ORDER FROM: University of Calgary Press 2500 University Dr. N.W. Calgary, Alberta, Canada T2N $1 N 4$

ISBN 0-919491-13-8

The Canadian Journal of Philosophy

is abstracted and indexed in

Academic Abstracts and

Social Science Source,

call toll free:

800-653-2726,

or write:

83 Pine Street, Peabody, MA 01960 


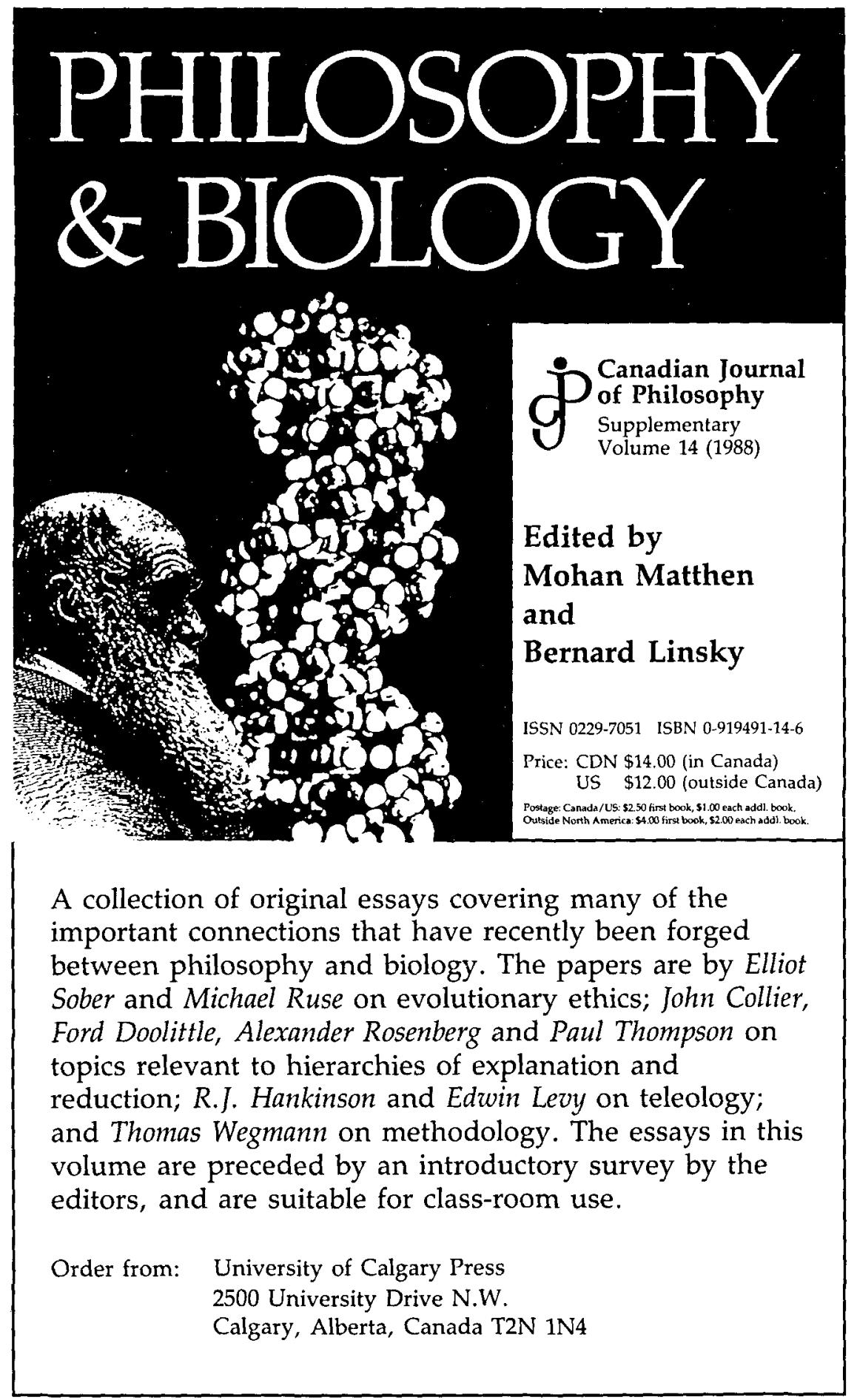




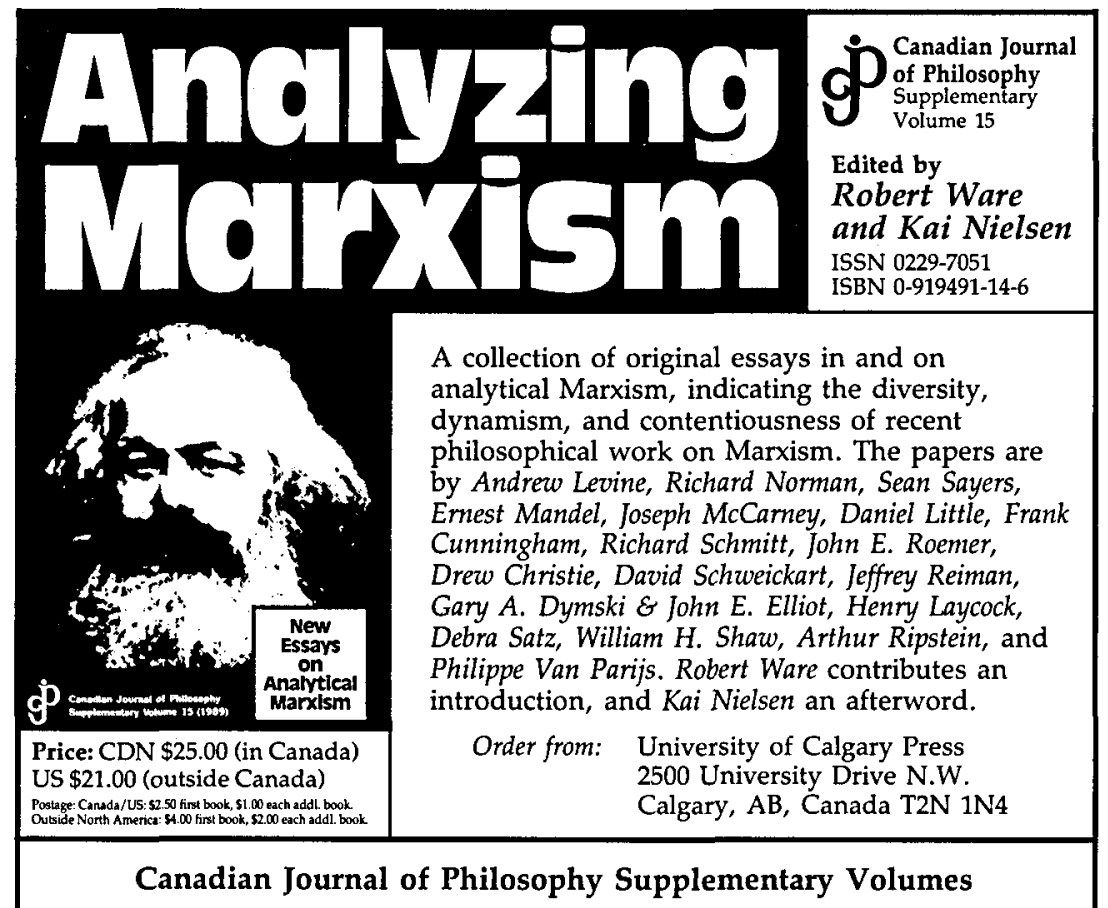

New Essays in the History of Philosophy

New Essays in the Philosophy of Mind

New Essays on Plato and the Pre-Socratics

New Essays in Contract Theory

New Essays on Rationalism and Empiricism

New Essays on John Stuart Mill and Utilitarianism

New Essays in Philosophy of Language

Marx and Morality

New Essays in Ethics and Public Policy
New Essays on Plato

New Essays on Aristotle

New Essays in Philosophy of Mind, Series II

Nuclear Weapons, Deterrence, and Disarmament

Science and Morality \& Feminist Theory

Philosophy \& Biology

Analyzing Marxism

Canadian Philosophers

Aristotle and his Medieval Interpreters
The Caradian Journal of Philosophy is published quarterly, in March, June, September and December. In addition to these regular issues, the C.J.P. publishes annually a supplementary volume of original papers on a selected theme of contemporary philosophical. interest. This supplementary volume is free to individual and student subscribers to the journal in that year. Supplementary volumes may also be purchased separately.

Correspondence regarding subscriptions, renewals, single issues and supplementary volume orders should be addressed to Canadian Journal of Philosophy c/o

University of Calgary Press, 2500 University Dr. N.W., Calgary, Alberta, Canada T2N 1 N4.

1993 volume/four issues:

Institutions

Individuals

Canada

Cdn. $\$ 40.00$

25.00

Foreign

Students

Single Issues

15.00

9.00

Analyzing Marxism:

$\$ 25.00$
US $\$ 40.00$

25.00

15.00

9.00

21.00
University of Calgary Press 2500 University Drive N.W.

CALGARY, Alberta, Canada T2N 1N4

Individual $\square$ Student $\square \times$

ANALYZING MARXISM Postage

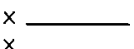

Please send me information on C.J.P. Supplementary Volumes

Name

Address

City

Country Postal Code

Visa $\square \quad$ Mastercard $\square$

No. Expiry Date

Signature 


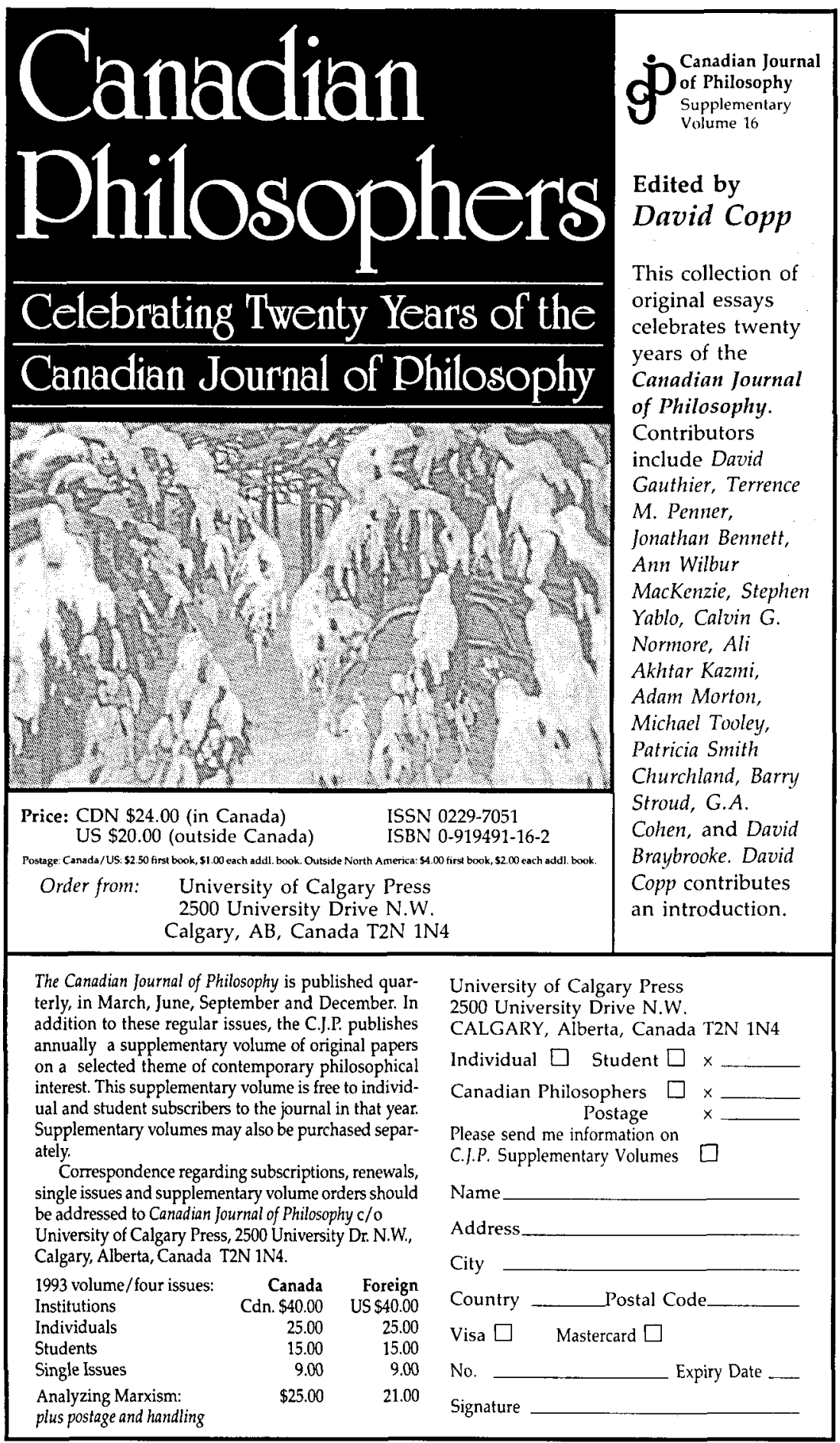



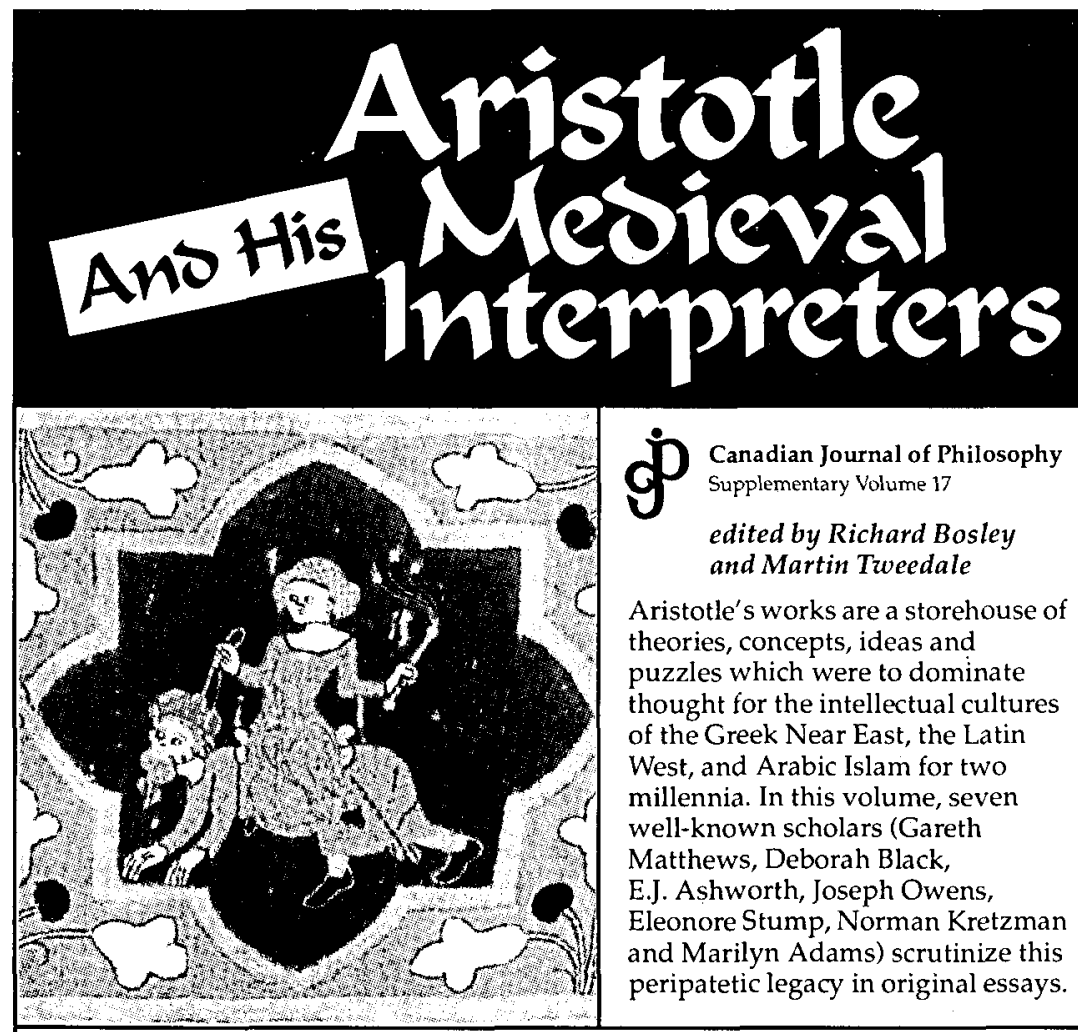

Aristotle's works are a storehouse of theories, concepts, ideas and puzzles which were to dominate thought for the intellectual cultures of the Greek Near East, the Latin West, and Arabic Islam for two millennia. In this volume, seven well-known scholars (Gareth Matthews, Deborah Black, E.J. Ashworth, Joseph Owens, Eleonore Stump, Norman Kretzman and Marilyn Adams) scrutinize this peripatetic legacy in original essays.
Price:
$\$ 21.00$ (Canadian)
$\$ 21.00$ U.S. (Foreign)
ISSN 0229-7051
ISBN 0-919491-17-0
Postage and handling (Canada and US) is $\$ 2.50$ for the first book and $\$ 1.00$ for each additional book. Postage and handling (outside North America) is $\$ 4.00$ for the first book and $\$ 2.00$ for each additional book. Canadian residents, please add $7 \%$
Order University of Calgary Press
from: 2500 University Drive N.W. GST to the total cost of the book(s) plus the Calgary, Alberta, Canada T2N 1N4 postage and handling.

The Canadian Journal of Philosophy is published quarterly, in March, June, September and December. In addition to these regular issues, the C.I.P. publishes annually a supplementary volume of original papers on a selected theme of contemporary philosophical interest. This supplementary volume is free to individual and student subscribers to the journal in that year. Supplementary volumes may also be purchased separately.

Correspondence regarding subscriptions, renewals, single issues and supplementary volume orders should be addressed to Canadian lournal of Philosophy, c/o University of Calgary Press, 2500 University Drive N.W., Calgary, Alberta, Canada T2N $1 \mathrm{~N} 4$.

1992 volume/four issues:

Institutions

Individuals

Students

Single issues

$\begin{array}{rr}\text { Canada } & \text { Foreign } \\ \text { Cdn. } \$ 40.00 & \text { US } \$ 40.00 \\ 25.00 & 25.00 \\ 15.00 & 15.00 \\ 9.00 & 9.00 \\ & \\ \$ 21.00 & \$ 21.00\end{array}$

University of Calgary Press

2500 University Drive N.W.

CALGARY, Alberta, Canada T2N 1N4

Individual $\square \quad$ Student $\square \quad \mathrm{x}$

Supplementary Vol. $17 \quad \square \quad \mathrm{x}$

Postage

Please send me information on C.J.P. Supplementary Volumes

Name

Address

City

Country Postal Code

Visa $\square \quad$ Mastercard $\square$

No. Expiry Date 


\title{
REVUE PHILOSOPHIQUE DE LOUVAIN
}

\author{
Fondée en 1894 par D. Mercier
}

Publiée par l'Institut Supérieur de Philosophie de l'Université catholique de Louvain. Parait quatre fois par an.

Directeur: $\mathrm{Cl}$. Troisfontaines. Comité de rédaction: J. ÉtIenne, G. Florival, J. Ladrière, J. Taminiaux, Georges Van Riet, F. Van Steenberghen.

Adresse de la rédaction: Collège Thomas More (SH3), Chemin d'Aristote 1, B-1348 LouvaiN-LA-Neuve, Belgique.

Service des abonnements et administration: E. PEeTERS, B.P. 41, B-3000 Louvain, C.C.P. 000-0425099-45.

Abonnement: 2000 FB. Numéro séparé: 600 FB (port en sus). Abonnement à la Revue philosophique de Louvain et au Répertoire bibliographique de la philosophie: $3200 \mathrm{FB}$.

Novembre 1992

Métaphysique et ontologie. Etudes sur la métaphysique d'Aristote.

J. Follon, Le concept de philosophie première dans la "Métaphysique" d'Aristote.

P. DESTRÉE, "Physique» et "métaphysique» chez Aristote. A propos de l'expression o้v ที ŏv.

G. GERARD, De l'ontologie à la théologie. Lecture du livre $Z$ de la «Métaphysique" d'Aristote.

Ch. RutTEN, La stylométrie et la question de "Métaphysique» $K$.

L. Couloubaritsis, Le statut de l'Un dans la "Métaphysique".

S. LofTs, Une nouvelle approche de la philosophie d'Ernst Cassirer.

L. Rizzerio, Coup d'xil sur la philosophie italienne contemporaine: Le "trascendentalismo della prassis et la philosophie critique de M. Dal Pra.

Comptes rendus: Philosophie moderne et contemporaine.

Chaque article est suivi d'un résumé en français et en anglais.

\section{crítica}

\section{REVISTA HISPANOAMERICANA DE FILOSOFIA}

Vol. XXIV / No. 71 / México, agosto 1992

\section{SUMARIO}

\section{Antículos}

ALEJANDRO CASSINI, Realismo epistemológico, referencia y verosimilitud

JULIÁN GARRIDO GARRIDO, Verdad como correspondencia con los hechos

LUIS A. PISCOYA HERMOZA, El compromiso valorativo de la tecnología

GEORGE ENGLEBRETSEN, Plus and Minus

Notas bibliográficas

JAMES E. TOMBERLIN (comp.), Philosophical Perspectives, 5

Philosophy of Religion, 1991 [AJejand ro Tomasini Bassols]

Publicaciones recientes

CRITICA, Revista Hispanoamericana de Filosofía, se publica en abril, agosto y diciembre, toda correspondencia debe dirigirse a CRITICA, Apartado 70-447, Coyoacán, 04510-México, D. F. México. 
the review of

metaphysics

a philosophical quarterly

ISSN 0034-6632

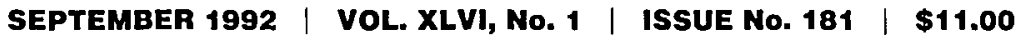

articles

books received

philosophical abstracts

doctoral dissertations

visiting philosphers

retiring philosophers

announcements

MARY T. CLARK

An Inquiry Into Personhood

R. F. HASSING

Animals Versus the Laws of Inertia

AMELIE OKSENBERG RORTY The Directions of Aristotle's Rhetoric

STEVEN B. SMITH

Hegel on Slavery and Domination

R. J. HENLE

Shopenhaver and Direct Realism

MATTHEW CUDDEBACK AND STAFF

Summaries and Comments

philosophical abstracts announcements

Individual Subscriptions $\$ 25.00$ Institutional Subscriptions $\$ 42.00$

Student/Retired Subscriptions $\$ 15.00$ 


\section{JOHN R. WETTERSTEN}

The Roots of Critical Rationalism. Amsterdam/Atlanta, GA 1992. 254 pp. (Schriftenreihe zur Philosophie Karl R. Poppers und des Kritischen Rationalismus 3)

ISBN: 90-5183-352-0

Hfl. 100,-/US-\$ 50.-

John Wettersten's book traces the historical and intellectual roots of critical rationalism from the days of the Whewell-Mill classical debate to Popper's work, through the contributors of Johannes Mueller, Wilhelm Wundt, Hermann von Helmholz and Oswald Kulpe and the other members of the Würzburg school, especially Karl Bühler, Poppers Doktorvater. The value of the book is in its placement of Popper's philosophy in a historical context which clarifies and elaborates on and explains his concerns and initial problems and their significance in the culture to which he made such important contributions. Special attention is paid to the neglected aspect of his early work, namely the interaction between research in the psychology and the philosophy of learning. It presents the growth of Popper's philosophy from Selzian psychology through his somewhat more positivist phase and back then to the realism which he defended as a young beginner.

Joseph Agassi

USA/Canada: Editions Rodopi, 233 Peachtree Street, N.E., Suite 404, Atlanta, Ga. 30303-1504, Telephone (404) 523-1964, Call toll-free 1800-225-3998 (U.S. only), Fax (404) 522-7116

And Others: Editions Rodopi B.V., Keizersgracht 302-304, 1016 EX Amsterdam, The Netherlands. Telephone (020) 622.75.07, Fax (020) 638.09 .48 


\section{PHILOSOPHER}

\section{L'avenir de la philosophie au collégial}

Numéro 13, 1992

ISBN 2-9802484-28 ISSN 0827-1887

Le rôle de la philosophie dans le renouveau du $D E C$

Le renouveau de la formation au collégial : le rôle de la philosophie

L'enseignement de la philosophie au cégep : par-deld les spécialités

Jean-François Malherbe, $Y$ a-t-il un droil de mourir?

Jocelyne St-Amaud, L'euthanasie : enjeux éthiques et politiques

Francisco Bucio, L'occidentalité de la philosophie

Vinh-De Nguyen, La politique du développement durable :

voie ou impasse

Claude Lévesque, Portrait du philosophe en poète

Jean-Pierre Walsh, École et pédagogie

Marc Turgeon, L'enseignement de la philosophie devant

l'approche-programme et l'éducation interculturelle

Pierre Talbot, Formation fondamentale et culture humaniste

dans les Etudes collégiales

Michel Dufour et André Giguère, Le Saph

Robert Tremblay, Quelques idées pour un modeste écritoire

Richard Rorty, L'homme spéculaire, par Robert Hébert

Julien Freund, La décadence, par Yvon Roux

François Lepage, Éléments de logique contemporaine, par Richard Riopel

André Verdan, Karl Popper ou la connaissance sans certitude,

par Jacques $G$. Ruelland

Jacques Derrida, Donner le temps, par Pierre Després

Naïm Kattan, Le père : Essais, par Michel Jean

RÉDACTION : PHILOSOPHER, Collège Montmorency, 475, boul. de l'Avenir, Laval, Qc, H7N 5H9, Canada.

ABONNEMENT : PERIODICA, agence internationale d'abonnement, C.P. 444, Outremont, Qc, H2V 4R6, Canada. Tél : (514) 274-5468 ou 1-800-361-1431 (le Québec et l'Outaouais).

CANADA : 1 an (2 numéros) institutions $52 \$$, individus $29 \$$, étudiants $18 \$$ (TPS et TVQ incluses)

ETRANGER : individus 30\$, institutions $50 \$$. 


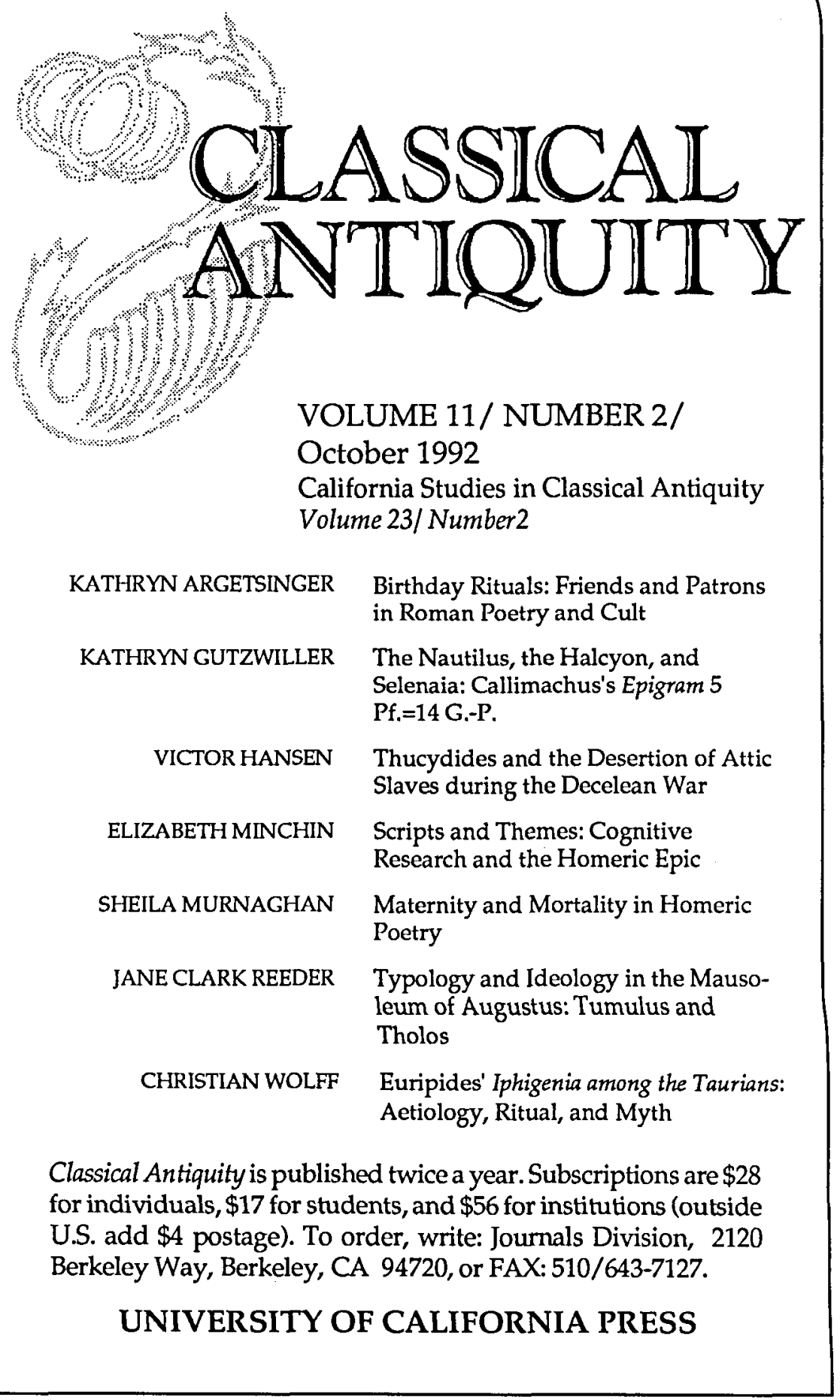




\title{
AUSTRALASIAN JOURNAL OF PHILOSOPHY
}

\author{
Editor: Robert Young
}

\section{SOME RECENT AND FORTHCOMING ARTICLES}

Nicholas Agar

John Bishop

Robyn Ferrell

André Gallois

Mark Heller

Jeanette Kennett

David Papineau
What Do Frogs Really Believe? Compatibilism and the Free Will Defence Why Bother: Defending Derrida and the Significance of Writing Is Global Scepticism Self-Refuting? Varieties of Four Dimensionalism Mixed Motives Physicalism, Consciousness and the Antipathetic Fallacy

Annual Subscription: Individuals A\$36 (US\$36 or Stg£18.00); Institutions A $\$ 62$ (US\$62 or Stg£91). All correspondence should be addressed either to the Editor or to the Business Manager, Australasian Journal of Philosophy, Department of Philosophy, La Trobe University, Bundoora, Victoria, 3083, Australia.

Published quarterly by The Australasian Association of Philosophy 


\section{Academic Printing and Publishing Books in Print 1992}

Peri Tōn Mathematōn

Essays on ancient mathematics and its later development

Edited by Ian Mueller

Original essays on Greek mathematics and its subsequent development by Arabic mathematicians. Contributors: Benno Artmann, Andrew Barker, Edward Hussey, Ian Mueller, Christian Marinus Taisbak, Roshdi Rashed, J.L.Berggren.

$\begin{array}{lllllr}\text { Price: } & \$ 54.95 & \text { cloth } & \$ 23.95 & \text { paper } & 1992 \\ \text { ISBN: } & 0-920980-50-3 & \text { cloth } & 0-920980-51-1 & \text { paper } & \text { vii }+251 \text { pp }\end{array}$

\section{The Poetics Of Therapy}

Hellenistic Ethics in its Rhetorical and Literary Context

edited by Martha Nussbaum

Original essays by leading scholars of Hellenistic thought about Hellenistic ethics and the ethical ideas in Hellenistic literature. The essays display the way in which attention to the rhetorical, literary and social dimensions of Hellenistic texts can enrich our philosophical and ethical understanding.

"Excellent pieces...A good deal of fresh writing and thinking in the volume" (Phronesis)

$\begin{array}{lllllr}\text { Price } & \$ 48.95 & \text { cloth } & \$ 21.95 & \text { paper } & 1991 \\ \text { ISBN } & 0-920980-46-5 & \text { cloth } & 0-920980-47-3 & \text { paper } & \text { viii }+297 \text { pp }\end{array}$

\section{Nature, Knowledge and Virtue \\ Essays in memory of Joan Kung \\ edited by Terry Penner and Richard Kraut}

Original essays on Plato and Aristotle by leading scholars, in memory of another.

Contributors: Kathleen Cook, Allan Gotthelf, Charles Kahn, Mohan Matthen, Gareth Matthews, Fred Miller, Deborah Modrak, Ian Mueller, Theodore Scaltsas, Nicholas White, Charlotte Witt

$\begin{array}{lllllr}\text { Price } & \$ 44.95 & \text { cloth } & \$ 19.95 & \text { paper } & 1990 \\ \text { ISBN } & 0-920980-34-1 & \text { cloth } & 0-920980-35-X & \text { paper } & \text { xiii }+233 \text { pp }\end{array}$




\section{Canadian Philosophical Reviews}

Revue Canadienne de Comptes rendus en Philosophie

\section{SALE of BACK ISSUES}

Volume I (1981) to Volume XI (1991) inclusive

All Back Issues of Canadian Philosophical Reviews/Revue

Canadienne de Comptes rendus en Philosophie are still available, and are now being offered at a reduced price.

\section{$\$ 40.00$ per volume}

Canadian funds for Canadian purchasers US funds for all non-Canadian purchasers

Shipping and handling extra GST extra for Canadian purchasers

Order from: Academic Printing and Publishing P.O. Box 4218

Edmonton, Alberta, Canada T6E 4T2

NB: Please note NEW P.O. Box number and postal code. Please change your records. Mail to the old box number will be forwarded.

Telephone and FAX number remain unchanged.

Tel: (403) 435-5898 FAX: (403) 435-5852

Or from your usual agent 
Acknowledgements/

Remerciements
The Canadian Journal of Philosophy is published with the aid of a grant from the Social Sciences and Humanities Research Council of Canada.

La publication du The Canadian Journal of Philosophy est rendue possible grâce à une subvention du Conseil de Recherches Humaines du Canada.

The Canadian Journal of Philosophy wishes to thank the University of Lethbridge for its generous support for the editorial administration of the journal.

The Canadian Journal of Philosophy tient à remercier l'Université de Lethbridge de l'aide généreuse qu'elle apporte à la gestion de sa rédaction.

The Canadian Journal of Philosophy is grateful for past support from its originating sponsor, the Canadian Association for Publishing in Philosophy. The Association is a non-profit organization, incorporated under the laws of Canada, with the object of promoting and publishing learned publications in philosophy. A regular member of the Association is a member of, and appointed by, any department of philosophy in a Canadian university, upon payment of a subscription by that department. The Association is a Registered Canadian Charitable Organization within the meaning of the Income Tax Act; donations to the Association are thus tax deductible.

The Canadian Journal of Philosophy désire exprimer sa gratitude à l'Association Canadienne des Publications en Philosophie qui l'a aidé par le passé. L'Association est un organisme à but non lucratif, incorporé aux termes de la loi canadienne, ayant pour objet la promotion et la publication d'études savantes en philosophie. Tout membre appartenant à, et désigné par, un département de philosophie d'une université canadienne est de facto, au reçu du règlement de l'abonnement départemental, membre à part entière de l'Association. L'Association est inscrite au Registre officiel des Organismes de Charité canadiens aux termes de la loi de l'impôt sur le revenu; les donations dont elle fait l'objet peuvent bénéficier ainsi du dégrèvement d'impôt. 